\title{
What is Maimonidean Scepticism?
}

Nowadays we call a philosopher a sceptic when he denies that knowledge is possible, and scepticism is a problem in epistemology, indeed a problem for its very possibility. Since Descartes, the sceptic is also prone to raise radical, hyperbolic doubts like demon deceivers or brains-in-a-vat that challenge ordinary beliefs or common knowledge like the existence of an external world or the existence of other minds. It is no surprise, then, that the contemporary sceptic is someone primarily to be rebutted, his doubts exposed as not just unjustified but even pathologically abnormal. Scepticism nowadays is a disease whose cure is refutation.

In antiquity, it was different. Faced with conflicting perceptual appearances, and the resulting anxiety and unhappiness of not knowing which one to believe, one initiated enquiry in order to discover what is true and what the real natures of things are, to reveal what to believe with security and thereby achieve some modicum of happiness. But lo and behold, scientific enquiry led to new and additional conflicts, not among appearances but between equally strong but opposing theories between which the inquirer had no clear reason to believe one rather than the other. Not yet freed from uncertainty and unhappiness, the rational reaction for the inquirer was not to assert that knowledge is impossible-for that would also be a claim that would raise conflict with others-but rather to suspend judgment, to refrain from assertion, i.e., from commitments about what is real and true. Unlike the dogmatist who claims to have reached his destination, the truth, the sceptic instead continues the enquiry, never terminating his search with any final determination, which would once again make him vulnerable to a conflicting assertion, and more unhappiness. This indeed was the original meaning of skepsis: unceasing enquiry or investigation, not doubt or the denial of knowledge. By suspending all judgment, by divesting himself of the anxious drive to achieve knowledge, thereby circumventing the source of unhappiness, the sceptic ipso facto finds himself in a state of happiness, if only tranquillity or peace of mind. In sum, for the ancients, scepticism was not the disease, but a cure to the dogmatist's unhappy condition that results from his unsatisfiable pursuit of the true natures of things in which to believe. ${ }^{1}$

\footnotetext{
I wish to thank Gad Freudenthal for originally suggesting to me that I write a précis of my book, The Matter and Form of Maimonides' Guide, as well as the Maimonides Centre for Advanced StudiesJewish Scepticism for hosting me as a senior fellow in 2016-17 while I wrote this paper and presented it at the Centre's International conference on scepticism.
}

1 This, of course, is an oversimplified presentation of ancient scepticism that, among other things, does not distinguish between Academics and Pyrrhonians. For a more nuanced, critical presentation, see Myles Burnyeat, “Can the Skeptic Live His Skepticism?” in The Skeptical Tradition, ed. Myles Burnyeat, (Berkeley: University of California Press, 1983), 117-48; Michael Frede, “The Skeptic’s Belief,” in 
According to the lore of our forefathers, after the third century CE, scepticism dropped out of sight during the Middle Ages. Over the past quarter century, this received view has now been corrected by distinguished scholars such as Dominik Perler, Robert Pasnau, and Henrik Lagerlund, who mainly draw on evidence culled either from early Christian thought, such as Augustine's Contra Academicos, or from late thirteenth through fourteenth century Latin philosophy, beginning with John of Salisbury, continuing through Henry of Ghent, Siger of Brabant, Scotus, Ockham, and Nicholas of Autrecourt. ${ }^{2}$ In the Islamic world, one finds mention of al-Ghazālī, who survived a short bout of scepticism and some of whose sceptical arguments anticipate Hume and Descartes. ${ }^{3}$ In this paper, I want to sketch in broad strokes a sceptical philosophy put forth in the Arabic philosophical world, not in the writings of a Muslim but of arguably the greatest medieval Jewish philosopher, Moses Maimonides $(1138-1204) .^{4}$

To call Maimonides a sceptic, or someone with sceptical leanings, will be a surprise for those who know him, as he has traditionally been cast, as a card-carrying

Essays in Ancient Philosophy (Minneapolis: University of Minnesota Press, 1987), 179-200; Frede, "The Skeptics's Two Kinds of Assent and the Question of the Possibility of Knowledge," in Essays in Ancient Philosophy (Minneapolis: University of Minnesota Press, 1987), 201-22; Gisela Striker, "Academics versus Pyrrhonists, Reconsidered," in Cambridge Companion to Ancient Scepticism, ed. Richard Bett (Cambridge: Cambridge University Press, 2010), 195-207; Striker, “On the Difference between the Pyrrhonists and the Academics," in Essays on Hellenistic Epistemology and Ethics (Cambridge: Cambridge University Press, 1996) 135-49; Striker, "Scepticism as a Kind of Philosophy," Archiv für Geschichte der Philosophie 83, no. 2 (August 2001): 113-29; Striker, "Sceptical Strategies,” in Doubt and Dogmatism, ed. Malcolm Schofield, Myles Burnyeat, and Jonathan Barnes (Oxford: Oxford University Press, 1980), 54-83.

2 It is noteworthy that Richard Bosley and Martin Tweedale, eds. Basic Issues in Medieval Philosophy, second edition (Toronto: Broadview, 2006), an "interactive” anthology of medieval philosophy, contains a topical unit on "Skepticism," including readings from Augustine, Henry of Ghent, Siger of Brabant, John Duns Scotus, and Nicholas of Autrecourt. On medieval scepticism, see Henrik Lagerlund, "A History of Skepticism in the Middle Ages," in Lagerlund, ed. Rethinking the History of Skepticism. The Missing Medieval Background (Leiden, Boston: Brill, 2010), 1-28; Robert Pasnau, Thomas Aquinas on Human Nature: A Philosophical Study of Summa Theologiae, 1a, 75-89 (Cambridge: Cambridge University Press, 2002); Pasnau, "Science and Certainty," in Cambridge History of Medieval Philosophy, ed. Robert Pasnau (Cambridge: Cambridge University Press, 2010), 357-68; Dominik Perler, "Does God Deceive Us? Skeptical Hypotheses in Late Medieval Philosophy," in Rethinking the History of Skepticism: The Missing Medieval Background, ed. Henrik Lagerlund (Leiden, Boston: Brill, 2010), 1-28; Perler, "Skepticism," in Cambridge History of Medieval Philosophy, vol. 1, ed. Robert Pasnau (Cambridge: Cambridge University Press, 2010), 384-96; <litr=60>Perler, "Scepticism and Metaphysics," in The Oxford Handbook of Medieval Philosophy, ed. John Marenbon (Oxford: Oxford University Press, 2012), 546-65.

3 On al-Ghazālī's scepticism, see Taneli Kukkonen, “Al-Ghazali’s Skepticism, Revisited,” in Rethinking the History of Skepticism: The Missing Medieval Background, ed. Henrik Lagerlund (Leiden: Brill, 2010), 29-60.

4 As an overview of a sceptical reading of Maimonides's Guide and for reasons of space, this essay does not attempt to evaluate alternative and, in particular, dogmatic readings which would be necessary to make a full case on its behalf. For such an evaluation of dogmatic readings, see Josef Stern, The Matter and Form of Maimonides' Guide (Cambridge: Harvard University Press, 2013). 
Aristotelian, Neoplatonist, or Rationalist (whatever that means), or as a traditional pious rabbi. But, in fact, he was already read in the Middle Ages and either appreciated or criticised for his sceptical or agnostic views both by some of his greatest commentators-including his translator Samuel ibn Tibbon, Shem Tov b. Joseph ibn Falaquera, and Profayt Duran (Efodi)-and, among the Latin scholastics, by no less than Thomas Aquinas. ${ }^{5}$ However, this reading of Maimonides was eclipsed by Averroism in the later thirteenth and fourteenth centuries, and only during the last forty years has it re-emerged-indeed, as the catalyst for what I take to be the liveliest debate in contemporary Maimonidean studies.

The historical sources of Maimonides's scepticism are not known. To the best of our knowledge, none of the classical sceptical works were translated into Arabic (or Hebrew, including Philo's description of the Modes), although we have a good description of the Pyrrhonists and Academics in Saadia's Book of Doctrines and Beliefs (probably drawn from a doxography). Galen and the medical tradition are a possible avenue of transmission, and specific sceptical arguments surface not infrequently in the Arabic literature. ${ }^{6}$ Arabic terms like wuqūf or tawaqquf and takāfu' al-adilla have been identified as translations of epochē and isostheneia; sceptics were known as šākkūn, ğuhhāl, mutağāhilūn, hịsbānīya, mu'ānida, lā adrīya, and sūfisțā'̄ya, a term by which Maimonides refers to those who doubt the senses, a view he attributes to the kalām. ${ }^{7}$ At the end of the day, Maimonides's sources remain a mystery, and we

5 Based on a close reading of Aquinas' Commentary on the Sentences, in which we can see him working out the positions and their sources later expressed in their mature form in the Summas, Richard Taylor argues that Aquinas read not only Maimonides as a sceptic about God and His attributes, but also Avicenna through a Maimonidean lens. See Richard Taylor, "Maimonides and Aquinas on Divine Attributes: The Importance of Avicenna," in Maimonides' Guide of the Perplexed in Translation: A History from the Thirteenth Century to the Twentieth, ed. Josef Stern, James T. Robinson, and Yonatan A. Shemesh (Chicago: University of Chicago Press, forthcoming 2019). For further discussion of Maimonides's sceptical influence on Aquinas, see David B. Burrell, Knowing the Unknowable God: Ibn-Sina, Maimonides, Aquinas (Notre Dame: University of Notre Dame Press, 1986); Idit Dobbs-Weinstein, Maimonides and St. Thomas on the Limits of Reason (Albany: State University of New York Press, 1995); and Mercedes Rubio, Aquinas and Maimonides on the Possibility of the Knowledge of God. An Examination of the Quaestio de attributis (Dordrecht: Springer, 2008).

6 See Saadia Gaon, Sefer Emunot we-De'ot [in Hebrew,] trans. Joseph Qafih (Jerusalem: Surah Press, 1969/70), 69-72. English translation in Saadia Gaon, The Book of Beliefs and Opinions, trans. Samuel Rosenblatt (New Haven: Yale University Press), 80-83. Saadia refers to the Pyrrhonists as those who hold the doctrine of wuqūf and the Academics as mutağāhilīn. See also Harry A. Wolfson, Repercussions of the Kalam in Jewish Philosophy (Cambridge, MA: Harvard University Press,1979), 160-62; Abraham Joshua Heschel, “The Quest for Certainty in Saadia’s Philosophy,” Jewish Quarterly Review 33, no. 3 (January 1943): 265-313.

7 On scepticism in the Islamicate world, see Saul Horowitz, Der Einfluss der griechischen Skepsis auf die Entwicklung der Philosophie bei den Arabern (Breslau: Schatzky, 1915); Josef van Ess, "Skepticism in Islamic Religious Thought," Al-Abhāt 21 (1968): 1-15; Patricia Crone, "Ungodly Cosmologies," in Islam, the Ancient Near East and Varieties of Godlessness: Collected Studies in Three Volumes, Volume 3, ed. Hanna Siurua, (Leiden: Brill, 2016), 124-27; Moshe Perlmann, "Ibn Hazm on the Equivalence of Proofs,” Jewish Quarterly Review 40, no. 3 (January 1950): 279-90; Franz Rosenthal, Knowledge Trium- 
also should not rule out the possibility that his scepticism was simply original to him.

We can date the beginning of the contemporary debate to an essay published in 1979 by Shlomo Pines, who argued that Maimonides adopted a position allegedly held by al-Fārābī in his lost Commentary on the Nicomachean Ethics according to which "the human intellect can only cognize objects perceived by the senses and images deriving from sense data." 0 n that basis Pines claimed that "Maimonides is of the opinion that no scientific certainty can be achieved with regard to objects that are outside the sub-lunar world," "thereby ruling out human cognition of the form, or concept, of any purely immaterial being like God and, indeed, of anything beyond the sublunary realm of terrestrial physics, thereby excluding cosmology and astronomy. However, the conclusion Pines drew from these epistemic limitations was that Maimonides, anticipating Kant, was a critical and not a sceptical philosopher. Lacking certainty that there exist separate intellects, Maimonides held, to quote Pines again, "there is no point in setting oneself the aim to intellect or to achieve a conjunction with a separate intellect," ${ }^{10}$ and instead Maimonides gave primacy to the life of political or practical action over that of intellectual perfection. ${ }^{11}$

phant (Leiden: Brill, 1970); Michael Cook, Early Muslim Dogma (Cambridge: Cambridge University Press, 1981); Stern, Matter and Form, 146-47, n25.

8 Shlomo Pines, "The Limitations of Human Knowledge According to Al-Farabi, Ibn Bajja, and Maimonides," in Studies in Medieval Jewish History and Literature, vol. 1, ed. Isadore Twersky (Cambridge: Harvard University Press, 1979), 93. I write that al-Fārābī allegedly held this view because, in the absence of the lost Commentary, all our evidence are reports by ibn Bāğğa, Averroes, and others, which has been recently challenged by Hebert A. Davidson, "Maimonides on Metaphysical Knowledge," Maimonidean Studies 3 (1995): 49-103; Davidson, Maimonides the Rationalist (Oxford: Littman Library of Jewish Civilization, 2011).

9 Pines, "Limitations," 93.

10 Pines, 94.

11 Pines claims that Maimonides should be characterised as a critical (rather than as a sceptical) philosopher. See Shlomo Pines, "The Philosophical Purport of Maimonides' Halakhic Works and the Purport of the Guide of the Perplexed," in Maimonides and Philosophy, ed. Shlomo Pines and Yirmiyahu Yovel (Dordrecht: Nijhoff, 1987), 11. See also Pines, "Dieu et L'Etre Selon Mamonide: Exégese d'Exode 3,14 et doctrine connexe," in Celui Qui Est: Interprétations Juives et Chrétiennes d'Exode 3-14, ed. Alain de Libera and Émilie Zum Brunn (Paris: Cerf, 1986), 15-24; Pines, "Les limites de la métaphysique selon al-Farabi, Ibn Bajja, et Maimonide: sources et antitheses de ces doctrine chez Alexandre d'Aphrodise et chez Themistius," Miscellanea Mediaevalia 13, no.1 (1981): 211-25; 1-14; Pines, "Translator's Introduction," in Maimonides, Guide of the Perplexed, translated by Shlomo Pines (Chicago: University of Chicago Press, 1963), 1:lvii-cxxxiv. Pines's thesis has generated a huge literature, some supporting but most challenging it. Those sympathetic to Pines or his general view include Warren Zev Harvey, "Maimonides' First Commandment, Physics, and Doubt," in Hazon Nahum: Studies in Jewish Law, Thought, and History, presented to Dr. Norman Lamm on the occasion of his seventieth birthday, ed. Jacob Elman and Jeffrey. S. Gurock (New York: Yeshiva University Press, 1997), 149-62; Warren Zev Harvey, “Maimonides' Critical Epistemology and Guide 2:24,” Aleph 8 (2008): 213-35; Kenneth Seeskin, Searching for a Distant God (Oxford: Oxford University Press, 1999); Joel L. Kraemer, "Is There a Text in this Class?” Aleph 8 (2008): 247-99; and Stern, Matter and Form. Critics include 
I believe that Pines put his finger on the pulse of the Guide but in calling Maimonides a sceptic rather than a critical philosopher, I intend to depart both from Pines's conclusion that Maimonides surrendered the theoretical and adopted a practical or political ideal for human happiness and from Pines's empiricist basis for Maimonides's epistemic limitations. On the other hand, I do not mean to claim that Maimonides neatly fits into ancient categories of scepticism, either Pyrrhonian or Academic. Since his dogmatists are the falāsifa, the Arabic (some more, others less Neoplatonised) Aristotelians, the conception of knowledge (epistēmē or 'ilm), that is the target of his sceptical critique is different from the Hellenistic models of belief that his predecessors were attacking. And because his scepticism is also, I shall argue, restricted to metaphysics, the specific arguments he gives differ from the modes one finds in, say, Sextus. ${ }^{12}$

Notwithstanding these differences, I will argue that Maimonides is best characterised as a sceptic for two main reasons: First, his arguments follow the sceptic's general argumentative schemata. In some cases, he deliberately gives for each argument for a proposition $p$ a counter-argument of equal strength for not- $p$ (or a contrary of $p$ ), resulting in a state of equipollence with respect to which the inquirer is brought to suspend judgment, epoche, and not assent to either proposition. In other cases, he shows how reasoning specifically about metaphysics leads to its own self-refutation and, again, epochē. And in almost all arguments, the deciding factor is the lack of a criterion-although what that criterion is differs for Maimonides from the Ancients. As with the Pyrrhonists, what is critical for scepticism for Maimonides is that the arguments lead to conflicting claims of equal strength, equipollence (in Greek, isosthe-

\footnotetext{
Alexander Altmann, "Maimonides on the Intellect and the Scope of Metaphysics," in Von der mittelalterlichen zur modernen Aufklarung (Tübingen: J.C.B. Mohr, 1987), 60-129; Herbert A. Davidson, "Maimonides on Metaphysical Knowledge"; Davidson, Maimonides the Rationalist; Charles H. Manekin, "Belief, Certainty, and Divine Attributes in the Guide of the Perplexed," Maimonidean Studies 1 (1990): 117-41; Manekin, "Maimonides and the Arabic Aristotelian Tradition of Epistemology," In Beyond Religious Borders: Interaction and Intellectual Exchange in the Medieval Islamic World, eds. David M. Freidenreich and Miriam Goldstein (Philadelphia, PA: University of Pennsylvania Press, 2011), 78-95; Barry S. Kogan, "What Can We Know and When Can We Know It? Maimonides on the Active Intelligence and Human Cognition," in Moses Maimonides and His Time, ed. Eric Ormsby (Washington D.C.: Catholic University of America Press, 1989), 121-37; Alfred Ivry, "The Logical and Scientific Premises of Maimonides' Thought." In Perspectives on Jewish Thought and Mysticism, edited by Alfred. L. Ivry, Elliot R. Wolfson, and Allan Arkush (Amsterdam: Harwood, 1998), 63-97; Ivry, "Guide 2:24 and All That (i)jâza," Aleph 8 (2008): 237-46.

12 Another difference I cannot discuss here for reasons of space is that, unlike the classical sceptics, who generally adopted metriopatheia, or moderation, as their stance towards moral behaviour and the emotions, Maimonides advocates apatheia, the eradication of (moral) emotions and bodily urges (to the highest degree possible) and, where that is not possible, their minimisation as a form of accommodation to necessity. This difference reflects Maimonides's Neoplatonic negative valuation of all things material or bodily. See Stern, Matter and Form, chapter 7. Because the body is physical or natural, this stance is again compatible with his scepticism about metaphysics but it yields a rather different picture than that of the classical sceptics.
} 
neia). It is not sufficient to raise $a$ doubt, the least possibility that would challenge the certainty of the knowledge claim. Second, the value Maimonides sees in suspension of judgment, epoche, or the self-refutation of reasoning, is never simply theoretical but also practical: to put oneself in a state of mind either of tranquillity, hence, a kind of happiness, and/or of awe and dazzlement that is an analogue to the kind of divine worship that the dogmatist holds one can achieve through the acquisition of positive knowledge about God. For Maimonides as for the Ancients, scepticism is always in the service of a practical end..$^{13}$

In order to sharpen these two motivations for characterising Maimonides as a sceptic, I will begin by spelling out the dogmatic background to which he is reacting.

From the start to finish of the Guide, Maimonides emphasises time and again that the true human self is the intellect and that true human perfection is intellectual:

[The human's] ultimate perfection is to become rational in actu, I mean to have an intellect in actu; this would consist in his knowing everything concerning all the beings that is within the capacity of man to know in accordance with his ultimate perfection (Guide 3:27, 511). ${ }^{14}$

The true human perfection [...] consists in the acquisition of the rational virtues-I refer to the conception of intelligibles, which teach true opinions concerning the divine things. This is in true reality the ultimate end; this is what gives the individual true perfection, a perfection belonging to him alone; and it gives him permanent perdurance; through it man is man $(3: 54,635)$.

Within Maimonides's Neoplatonised Aristotelian philosophical world, one achieves this ideal human perfection through full actualisation of one's intellectual potentiality: one acquires all possible concepts and truths-of physics, cosmology, and metaphysics-and then contemplates or uses these truths in theoretical reasoning constantly, exclusively, and continuously. The individual who achieves this intellectual state is as close as one can be to a disembodied (separate) intellect. This is the philosophers' ideal, and it is also Maimonides's ideal. ${ }^{15}$

But that leaves open the question-the core of the current controversy-as to whether Maimonides believed that this ideal of intellectual perfection can be realised or achieved by real human beings. The obstacle is that the human being for Maimo-

13 See Burnyeat, "Can the Skeptic," on the practical dimension of scepticism in particular and, on ancient philosophy in general, Pierre Hadot, Philosophy as a Way of Life, ed. Arnold I. Davidson, trans. by Michael Chase (Oxford: Blackwell, 1995); Hadot, What is Ancient Philosophy? Trans. Michael Chase (Cambridge: Harvard University Press, 2002).

14 References to the Guide appear in parentheses in the body of the text according to book number and book chapter, followed by the page number in Pines's English translation.

15 Pines argued that, because of his critical epistemology, Maimonides gives up the theoretical ideal in the closing paragraph of the Guide 3:54 and opts for a life performing acts of loving-kindness, righteousness, and judgment through assimilation to God's actions which he interprets as civic or political happiness. This move has been criticised by many. For an alternative explication of this passage, see Stern, Matter and Form, 340-49. 
nides is necessarily a hylomorphic substance composed of matter/body and form/intellect: there can be no form without matter and no matter without form. But this in turn raises the question whether the human's matter/body absolutely prevents her from achieving the perfection of her form/intellect. More specifically, (1) does one's matter/body, which includes bodily faculties like the imagination, prevent one from purely intellectual apprehension of metaphysics and the heavens; and (2) do bodily needs and desires prevent one from constantly, exclusively, and undividedly attending to and engaging in intellectual activity with the requisite concentration to be a fully actualised, constantly active intellect? If we answer yes to either question, the tension between the human's intellect and body leaves her at most with an incomplete grasp of metaphysics and with significantly less continuous and less intensive intellectual activity than what perfection demands.

In response to this open question, readers of the Guide fall into two camps. Dogmatic readers hold that Maimonides believed that the ideal of intellectual perfection is humanly realisable; hence, it must be possible for human beings to acquire knowledge of metaphysics, cosmology, and God. Sceptical readers hold that Maimonides did not believe this is possible for the reason that, as Maimonides states, "matter is a strong veil preventing the apprehension of that which is separate from matter as it truly is" (3:9, 436-37). Here "matter" signifies the imagination, which, as a bodily faculty, cannot conceive or represent anything except as a body, i.e., a subject or substance with attributes, a kind of compositeness or complexity that conflicts with the simplicity of the immaterial. But without knowledge, or apprehension, of the immaterial, there is no knowledge of metaphysics, hence, no absolute perfection of the intellect and no happiness consequent to that state.

In other words, dogmatic readers of the Guide identify Maimonides's views with those of his dogmatists, the falāsifa, the (more or less Neoplatonised) Arabic Aristotelians, like the earlier Al-Fārābī and Avicenna who, for all their differences, claim that perfected human intellects possess scientific knowledge of metaphysics that in turn enables conjunction or union with the Active Intellect and the highest kind of intelligible happiness. This widely-held identification of Maimonides with the falasifa is easily understandable. On traditional dogmatic readings of the Guide, it was assumed that, because Maimonides harshly attacks the kalām, and because the falāsifa are their enemy, then, on the assumption that the enemy of one's enemy is one's friend, he must identify himself in general with the falāsifa and their Aristotelian views. However, the full picture is much more complicated and nuanced. First, Maimonides's deepest objection to the kalām-one senses genuine revulsion-concerns their method or philosophical ideology: he depicts them as apologists, polemicists, and theological opportunists who, rather than "[...] conform in their premises to the appearance of that which exists, consider how being ought to be in order that it should furnish a proof for the correctness of a particular opinion" $(1: 71,178)$. They shape the facts to fit their theory rather than, as Themistius insisted, have "the correct opinions conform to that which exists" $(1: 71,179)$. However, on particular questions of significance for metaphysics and epistemology-especially on the nature of 
the modalities, the limits of causal explanation, and the evidence from the heavens for belief in a deity-Maimonides finds in the kalām not insignificant grains of truth and correctives to the philosophers' self-confidence in their claims to knowledge (see 1:73, 208; 211; 1:74, 219; 2:19, 303; 3:15, 460).

On the other hand, Maimonides is highly critical of the philosophers, especially on matters of metaphysics and cosmology. Of course, even given the received dogmatic picture, there are specific issues where Maimonides explicitly declares his disagreement with the philosophers, most notably that of creation vs. eternity. However, the default assumption is that where Maimonides cites the philosophers without indicating a disagreement, he agrees with them (and especially when he adds that the Law also agrees with them, for example, on the existence of separate intellects, namely, angels). Thus, it is frequently asserted that Maimonides accepts the philosophers' four proofs of the existence of God (in 2:1) and their doctrine of the unity of the intellect in act, its object, and subject (in 1:68). ${ }^{16}$ In fact, however, when he attributes a given view to the philosophers, it is arguable that he means to distinguish it as their view, not his, which he then attacks. ${ }^{17}$

Furthermore, on a number of subjects (prophecy, providence, cosmology), Maimonides adopts the familiar sceptical strategy of arguing ad hominem against the philosophers, avoiding dogmatic assumptions of his own by assuming his opponent's own assumptions and showing the antinomies or conflicting opinions to which they lead-recognition of which should lead these opponents to give up their assertions and suspend judgment. One such example is the philosophers' theory of separate intellects, which they use to explain the motions of the spheres, and

16 See Altmann, "Maimonides"; Davidson, Maimonides the Rationalist, 126-27, Ivry, "Logical and Scientific Premises," 73; Joel L. Kraemer, "How (Not) to Read The Guide of the Perplexed," Jerusalem Studies in Arabic and Islam 32 (2006): 350-403; Howard Kreisel, Maimonides' Political Thought: Studies in Ethics, Law, and the Human Ideal (Albany: SUNY Press, 1999); Tamar Rudavsky, Maimonides (Malden, MA: Wiley-Blackwell, 2010); Josef Stern, “Maimonides' Demonstrations: Principles and Practice," Medieval Philosophy and Theology 10 (2001): 47-84. To be sure, some among both the medieval commentators and modern scholars argue that even on issues like eternity vs. creation, despite his explicit statements, Maimonides esoterically agrees with the philosophers; see Leo Strauss, "The Literary Character of the Guide of the Perplexed," in Persecution and the Art of Writing (Glencoe: Free Press, 1952), 38-94; Warren Zev Harvey, "A Third Approach to Maimonides' Cosmogony-Prophetology Puzzle," Harvard Theological Review 74, no. 3 (July 1981): 287-301. On the other hand, the sceptical reading that distinguishes Maimonides's stance from the philosophers' does not claim that Maimonides sees no cognitive value in the views of the philosophers. Maimonides generally adapts the philosophers' positions as the kind of wisdom that is appropriate to communal welfare even if is not "the truth as it really is," i.e., what science would demonstrate. For further discussion, see Stern, Matter and Form, 12-15; 32-37.

17 See Maimonides's explicit statement distinguishing the philosophers' premises and "methods of inference" to prove the existence of the deity from "the method I shall adopt" in 1:71, 183-84. Likewise, the doctrine of the unity of the intellect is proposed as the "dictum of the philosophers" (1:68, 163). 
which Maimonides presents in detail only in order to launch a vigorous critique. ${ }^{18}$ In the same spirit, he provides a deep critique of their account of divine attributes, and in particular negative attributes (as we shall explain below). But at critical moments in the Guide, Maimonides also takes scepticism as his own stance and cultivates suspension of judgment as the correct reactive attitude toward all metaphysical problems, exercise of which will lead to peace of mind and/or worship of God. Yet even at those moments when it turns out (as the sceptical reader argues, on Maimonides's own view) that the intellectual ideal cannot be realised by human beings, it does not follow that Maimonides surrenders the ideal of intellectual perfection. Instead it continues to serve as a regulative ideal that orients and shapes a life of unending enquiry. However, what is necessary is that we re-evaluate how we measure perfection: whether we judge it solely in terms of the product-the content of the knowledge-attained, or whether we focus instead on the process and practices of intellectual activity and enquiry, regardless of whether or not they achieve their ends.

Where Maimonides agrees with the falāsifa is that all knowledge including metaphysics, and in particular knowledge of God (if possible), must be based on the natural world explained by sublunar science:

I have already let you know $[1: 34,74]$ that there exists nothing except God [...] and this existent world and that there is no possible inference proving His existence [...] except those deriving from this existent taken as a whole and from its details. Accordingly it necessarily behooves one to consider this existent as it is and to derive premises from what is perceived of its nature. For this reason it follows that you should know its perceptible form and nature, and then it will be possible to make an inference from it with regard to what is other than it $(1: 71,183)$.

But if the only route to knowledge of God is via "the existent world"-through the natural sciences-it follows that Maimonides does apparently believe that we do have knowledge of physics and nature. Indeed, he repeatedly states that "everything that Aristotle has said about all that exists from beneath the sphere of the moon to the centre of the earth is indubitably correct" $(2: 22,319$; cf. 2:24, 326). But not only is Aristotelian natural science true, it is also Maimonides's paradigm of scientific knowledge. Its demonstrations and proofs furnish standards and criteria that any other purported science or explanation, including divine science, or metaphysics, must meet. For example, what is metaphysically possible (or necessary) must both be compatible with and be constrained by nature as it actually is. And when he argues ad hominem against the falāsifa, the main fault he finds in their theories of cosmology and metaphysics is precisely their failure to live up to their own standards of knowledge given in their theories of physics.

The first moral to be drawn, then, for Maimonides's scepticism is that it is limited to what lies beyond physics, in particular the philosophers' cosmological and metaphysical theories. Elsewhere in the Guide, Maimonides explicitly disowns scepticism

18 See Stern, Matter and Form, 250-305. 
with respect to the senses $(1: 73,213-14)$, and he also allows for mathematical knowledge $(1: 31,66)$. He also makes every effort to insulate his scepticism from the natural sciences-although I am not as confident that his attempt at insulation or his distinction between the epistemic credentials of human knowledge of physics and of metaphysics is as stable as he thinks. ${ }^{19}$ Now, that one's sceptical stance can be restricted is not news; as we will next mention, Pyrrhonists also restricted their scepticism to non-evident beliefs, allowing themselves assent or at least acquiescence to the evident. ${ }^{20}$ However, Maimonides's distinction is between two domains or subject matters (nature or the sublunar world vs. cosmology and metaphysics), and the fact that his scepticism is limited to metaphysics enables him to make dogmatic assumptions about the sublunar world that the classical sceptic could not make-for example, assumptions about what human (scientific) knowledge requires, about physical motion, causation, matter, and form presupposed by physics, assumptions from which Maimonides launches his sceptical critique of the philosophers' theories of metaphysics.

A complementary restriction on Maimonidean scepticism is that it is directed exclusively against claims to possess scientific knowledge, the kind of cognitive state the calibre of which would enable the human, in medieval terms, to achieve the status of a fully actualised or acquired intellect that either is in or leads to conjunction with the active intellect. Unlike some interpretations of classical scepticism, Maimonides does not challenge ordinary or rustic beliefs or "common knowledge," let alone generally accepted or "conventional" opinions or dialectical conclusions, or

19 Notwithstanding all these statements avowing scientific knowledge of the sublunar world and the natural sciences, at least one medieval commentator and one modern scholar have appealed to a passage in 3:23, 496 to argue that Maimonides was also sceptical of knowledge of the sublunar sphere. See Shem Tov Ibn Falaquera, Moreh ha-Moreh, [Heb.,] ed. Yair Shiffman (Jerusalem: World Union of Jewish Studies Press, 2001), 274-77 and Warren Zev Harvey, "Maimonides' Critical Epistemology and Guide 2:24," Aleph 8 (2008): 234-35. I discuss this passage in Josef Stern, The Epistemology of Prophecy: Maimonides on the False Prophet (manuscript in preparation). The larger issue is whether our lack of knowledge of ultimate superlunar causes impugns our knowledge of the proximate sublunar causes. Suffice it to say for now that, although it is clear that Falaquera himself takes scepticism to extend both to the sublunar and superlunar worlds, all that Maimonides denies in that passage is knowledge of the "origination" of sublunar natural things, i.e., explanation by their ultimate causes in the superlunar sphere.

20 It is a subject of endless scholarly controversy how to characterise the evident/non-evident distinction: whether the evident are mere appearances that one passively receives, (non-epistemic) reports about one's own mental state rather than the world, or ordinary (rustic) beliefs as opposed to theory-embedded or scientific/philosophical (gentleman's) beliefs; see Jonathan Barnes, "The Beliefs of a Pyrrhonist," Elenchos 4 (1983): 5-43; Burnyeat, "Can the Skeptic”; Frede, "Skeptics's belief”; Frede, "The Skeptic's Two Kinds"; Striker, "Sceptical Strategies”; and Casey Perin, "Scepticism and Belief," in Cambridge Companion to Ancient Scepticism, ed. Richard Bett (Cambridge: Cambridge University Press, 2010), 145-64. 
claims accepted because they suffer from fewer doubts than rival hypotheses. ${ }^{21} \mathrm{Nei}-$ ther are his arguments directed against claims as to what really exists in the sublunar world or about the natures of things as opposed to their appearances.

Since he discusses certainty as a species of belief (1:50, 111), Maimonides's scepticism also does not exclude the possibility that someone may have certain belief in a proposition about which he has no knowledge or understanding, specifically concerning which he suspends judgment (I will sketch one example of this possibility). ${ }^{22}$ His term for scientific knowledge is most frequently ' $\mathrm{ilm}$, which translates the Greek epistēmē (less frequently, he uses ma'rifa). Like most of his philosophical terms, Maimonides nowhere explicitly defines 'ilm, and his use of the term is sometimes loose. ${ }^{23}$ Within the Aristotelian tradition, epistēmē is closely linked to demonstration (burhān) and to the intellect (' $a q l$ ). And among the conditions Aristotle requires for premises of a demonstration, the most important for Maimonides is that they must contain the cause, or explanation, of the conclusion. For in order to have scientific knowledge of $x$, one must understand $x$ according to its "true reality" (haqiqa), rather than as it appears or according to common opinion, and we only understand $x$ when we know its causal explanation. ${ }^{24}$ Aristotle goes on to distinguish explicitly between demonstrations that contain a middle term that is the cause and explanation of the conclusion, entailing both the fact that (to hoti; Arabic inna) the conclusion obtains and its explanation why (to dioti, Arabic limā) and those demonstrations that contain no cause and merely establish the fact that the conclusion is true. Among the scholastics, this distinction came to be known as the difference between demonstrations propter quid and quia, and I have argued elsewhere that only demonstrations propter

21 According to Alexander of Aphrodisias's principle; see Guide 2:3, 254; 2:23, 321. It is an intriguing question whether Alexander's principle may be related to the Academic's idea of reasonable or probable belief as a criterion in the absence of knowledge. On the status of Aristotelian (not kalām) dialectical arguments, see Joel L. Kraemer, "Maimonides on Aristotle and Scientific Method," in Moses Maimonides and His Time, ed. Eric Ormsby (Washington D.C.: Catholic University of America Press, 1989), 53-88; Arthur Hyman, "Demonstrative, Dialectical, and Sophistic Arguments in the Philosophy of Maimonides," in Moses Maimonides and His Time, ed. Eric Ormsby (Washington D.C.: Catholic University of America Press, 1989), 35-51; Ivry, "Logical and Scientific Premises.”

22 On certainty as an epistemic notion in Arabic philosophy, see Deborah L. Black, "Knowledge ( $\mathrm{Ilm}$ ) and Certitude (Yaqīn) in Al-Farabi's Epistemology," Arabic Sciences and Philosophy 16 (2006): 11-45, explicating al-Fārābī, Kitāb al-Burhān, in Al-Manțiq 'inda al-Fārābī, volume 4, ed. Majid Fakhry (Beirut: Dar al-Machreq, 1987). Partial English translation in Jon McGinnis and David C. Reisman, eds., Arabic Philosophy: An Anthology of Sources (Indianapolis: Hackett Publishing Company, 2007), 63-67. Manekin, "Maimonides," argues that Maimonides replaced explanatory understanding ( ilm or epistèmē) by certainty as the standard of demonstration, hence, of scientific knowledge. For criticism, see Stern, Matter and Form, 142-45, and Stern, Epistemology.

23 See Hyman, "Demonstrative”; Maimonides, Moreh Nevukhim [Hebrew,] trans. Michael Schwartz (Tel Aviv: Tel Aviv University Press, 2002), 1:7n12 (translator’s note); Stern, “Maimonides’ Demonstrations”; Stern, Matter and Form, 138-42.

24 See Myles Burnyeat, “Aristotle on Understanding Knowledge," in Aristotle on Science, ed. Enrico Berti (Padua: Antenore, 1981), 97-139. 
quid furnish what Maimonides, following Alexander of Aphrodisias, believes is necessary to achieve knowledge or understanding. ${ }^{25}$ I will return to this shortly, but the significant upshot for us is that the target of Maimonidean scepticism is exclusively scientific knowledge or understanding of metaphysics, not knowledge of physics and not even beliefs held with certainty about metaphysics.

Against this background, we can now turn to what I earlier called the practical orientation of Maimonidean scepticism. Maimonides does not simply make a theoretical case that the falāsifa and he himself (and generalising, all humans) lack the epistemic credentials for knowledge claims about metaphysics. He also makes the normative claim that, given a sceptical critique, one ought to "refrain and hold back," "stop," or "stand"-all translations of wuqūf, his term for epoche--upon recognising her lack of knowledge/understanding. But wuqūf or epochē is also not an end in itself. Rather it is a step, as we also saw for the classical sceptic, towards achieving a kind of happiness. For the Pyrrhonist, their non-eudemonian happiness is tranquillity (ataraxia), a certain kind of mental state, peace of mind, that follows almost as an accident (or so it is depicted) from epochē, the suspension of judgment on all questions. Maimonides, in contrast, describes two different practical states in the contexts of different arguments: one is also tranquillity, but the second is dazzlement or awe. First, he sees the sceptic's wuqūf as a way of freeing oneself from the unceasing anxiety, endless irresolvable disagreements, and bad science that result from the drive to satisfy the unsatisfiable epistemic desire to have knowledge of metaphysics.

When [studying "obscure matters like metaphysics"] one should not make categoric affirmations in favor of the first opinion that occurs to him and should not, from the outset, strain and impel his thoughts toward the apprehension of the deity; he rather should feel awe and refrain and hold back until he gradually elevates himself (1:5, 29; my emphasis).

[I]f you stay your progress because of a dubious point; if you do not deceive yourself into believing that there is a demonstration with regard to matters that have not been demonstrated; if you do not hasten to reject and categorically to pronounce false any assertions whose contradictories have not been demonstrated; if, finally, you do not aspire to apprehend that which you are unable to apprehend-you will have achieved human perfection and attained the rank of Rabbi Aqiba [...] who entered in peace [shalom] and went out in peace [shalom] when engaged in the theoretical study of these metaphysical matters (1:32, 68-69).

When points appearing as dubious occur to him or the thing he seeks does not seem to him to be demonstrated, he should not deny and reject it, hastening to pronounce it false, but rather should persevere and thereby have regard for the honor of his Creator [yahus 'al kevod qono]. He should refrain and hold back [Ar.: yaqif; Heb. ya'amod] $(1: 32,70)$.

In the first of these passages (1: 5), the "holding back" is in part an expression of caution in judgment, although the awe of the deity that motivates it and that it elicits hints at more. However, in the next two passages, the first of which alludes to an enigmatic rabbinic story of four scholars who entered a pardes, or orchard, which 
Maimonides interprets as the study of metaphysics, wuqūf, "staying your progress" and "stopping," is not merely not assenting to or not rejecting individual metaphysical propositions. Rather it is not aspiring or seeking to know what one cannot know. It is giving up or divesting oneself of the very aspiration or drive, and ipso facto tranquillity follows by freeing oneself of this source of unhappiness. The Hebrew word shalom, here peace of mind or tranquillity, plays on shelemut (Arabic kamāl), perfection. But this perfection is achieved without knowledge and, indeed, only when one does "not aspire to apprehend that which you are unable to apprehend," namely, the truths one seeks in "the theoretical study of these metaphysical matters." Hence, the perfection Maimonides recommends is not the unachievable intellectual one that requires literally knowledge of everything including metaphysics. Instead it is the perfection of the one who, having disavowed his own unsatisfiable epistemic desires, lacks no unfulfilled desire. At the same time, Maimonides makes clear that the point is not to give up intellectual enquiry and the intellectual ideal: "The intention [...] is not [...] wholly to close the gate of speculation and to deprive the intellect of the apprehension of things that it is possible to apprehend [...] Their purpose, in its entirety, rather is to make it known that the intellects of human beings have a limit at which they stop" $(1: 32,70)$. To stop at one's limits is ipso facto to redirect oneself back into enquiry into the domain of humanly achievable knowledge, physics, and the sublunar world. However, enquiry into natural sublunar phenomena leads one, naturally, as an inquisitive inquirer, to seek ultimate causes, hence, back into the realm of the unsatisfiable epistemic desire to have knowledge of metaphysics with all its ill effects, leading again to wuqūf/epochē, redirection to the sublunar, and so on. wuqū is the cure for the intellectual unhappiness that is due to unsatisfiable epistemic desires. But it is also part of a circular exercise of skepsis as persistent, unending enquiry that never ceases at a final destination of secure dogmatic knowledge of ultimate metaphysical causes.

The second result, or practical effect, of wuqū $f$ is an expression of divine worship -dazzlement, awe, spontaneous praise-that follows recognition of the limits of one's intellect. Just as Sextus tells us how Apelles achieved the effect of a horse's foam only when he gave up and flung his sponge at the canvas, so Maimonides depicts how at the very moment that his sceptic suspends judgment about metaphysical knowledge through the discipline of self-imposed limits on his intellect, he puts (or, better, finds) himself in a state of awe and dazzlement in the presence of God, the metaphysical object par excellence-analogous to the state of divine worship that the dogmatist seeks to achieve through the acquisition of positive knowledge about metaphysics and God. For example, following an antinomy concerning divine attributes (to which we will return), he exclaims:

All men, those of the past and those of the future, affirm clearly that God [...] cannot be apprehended by the intellects, and that none but He Himself can apprehend what He is, and that apprehension of Him consists in the inability to attain the ultimate term in apprehending Him (1:59, 139). 
Glory then to Him who is such that when the intellects contemplate His essence, their apprehension turns into incapacity $[. .].(1: 58,137)$.

For the governance and the providence of [God] accompany the world as a whole in such a way that the manner and true reality of this accompaniment are hidden from us; the faculties of human beings are inadequate to understand this. On the one hand, there is a demonstration of His separateness, may He be exalted, from the world and of His being free from it; and on the other hand, there is a demonstration that the influence of His governance and providence in every part of the world, however small and contemptible, exists. May He whose perfection has dazzled us be glorified (1:72, 193, my emphasis).

[Following the interpretation of the parable of the Garden of Eden and Adam's "sin":] Praise be to the Master of the will whose aims and wisdom cannot be apprehended (1:2, 26).

In each of these cases, Maimonides works us through a process of sceptical reasoning leading to an equipollence of contrary propositions, followed by wuqūf. Treating this process as a Hadot-like spiritual exercise, he shows us how one puts oneself into a state in which one cannot but express awe and spontaneous praise of God-analogous or parallel to the state the dogmatist sought to achieve through the acquisition of positive knowledge of God.

One final feature of the Maimonidean sceptical programme that I will just mention-but, for reasons of space, not elaborate-is its distinctive brand of exegesis whose central element is the parable and the parabolic interpretation of texts in Scripture, Rabbinic literature, ancient philosophy, and of Maimonides's own making. ${ }^{26}$ Maimonides's use of the parable is not, however, as it is usually presented, to control the dissemination of knowledge fully grasped by its author. Rather the parable serves him as a medium for the expression of its author's incomplete, partial, flash-like grasp of metaphysics. Maimonides begins the Guide with a rich parable depicting an inquirer's intellectual experience when engaged in enquiry into metaphysics, using images of a tug of war of perplexity and lightning-like flashes in dark night to capture the fact that none of "the great secrets [of metaphysics] are fully and completely known to anyone among us," i.e., all humans (1:Introduction, 7). The parable, he continues, is the primary verbal form by which his ancient predecessors among the prophets, rabbis, and Greek philosophers, for example, Plato, attempted to put this intellectual experience into words. Following suit, Maimonides composes his own parables to express his incomplete understanding of metaphysics. Interpreting the proverb "A word fitly spoken is like apples of gold in filigree, or finer tracery, of silver" (Proverbs 24:11) as itself a parable about the interpretation of parables, Maimonides argues that the multi-levelled semantic structure of a parable corresponds to the structure of the cognitive experience of incomplete understanding of metaphysics. He shows how we begin by working through propositions that are commonly believed but not scientifically demonstrated. These constitute the parable's external meaning and often turn out to express the Aristotelian position. Next we focus 
on their implications and presuppositions and thereby expose problems, inconsistencies, and antinomies. Through this cognitive process, one comes to grasp what one can of the parable's inner meaning: an incomplete grasp of metaphysics and a sceptical acquiescence to the limits of one's understanding.

To give a feel for the character of Maimonides's scepticism with respect to knowledge of metaphysics and, in particular, God, I now turn to two of his arguments, sketched in broad strokes.

Recall Pines's empiricist claim that all knowledge for Maimonides must be abstracted from sensible images, thereby excluding the intelligible forms of purely immaterial beings, such as the Active Intellect or God. The dogmatist will object that we may not be able to directly apprehend or perceive intelligible forms of immaterial beings, but we can come to know general metaphysical propositions by inference, abstracting physical concepts (for example, body, time, and space) and more general intelligible concepts (such as unity, cause, simple, and incorporeal), combining them into propositions, building syllogisms, constructing a science, and demonstrating general propositions, say, that there is one simple, incorporeal, first cause of the universe-and this is God. ${ }^{27}$ In reply to this dogmatic counter-argument, the sceptic must explain why the falāsifa's demonstrations, their indirect proofs for metaphysical theses, do not meet the standards of scientific knowledge. As I have mentioned, the source of the problem is materiality and in particular the bodily faculty of the imagination.

The strongest case a dogmatist could make for the possibility of knowledge of metaphysics would be to produce a full-fledged demonstration for an unquestionable metaphysical proposition such as the existence of the deity. ${ }^{28}$ Maimonides seems to refer to such a proof in the following three passages:

27 See Altmann, “Maimonides”; Davidson, "Maimonides on Metaphysical Knowledge”; Davidson, Maimonides the Rationalist. For discussion, see Davidson, Maimonides the Rationalist, 65-66. Additional examples of metaphysical propositions that are said to have been demonstrated are found in Guide 1:58, 135; 1:59, 137-39; 1:68, 163; 165; 1:71, 180-81;1:76, 227; 2:1, 246, 252; 2:4, 256; cf. Davidson, Maimonides the Rationalist, 173-74. In some of these cases, however, it is the philosophers who claim to have demonstrated them; in others, we are given what is designated a "proof" (dalil) which may or may not be a demonstration.

28 Such a "full-fledged" demonstration would ideally be a demonstration propter quid of the existence of God, a demonstration containing among its premises the cause, or explanation, of the conclusion that God exists. A purported demonstration of this kind is, for example, Anselm's ontological proof which is, in turn, criticised by Aquinas in the Summa Theologiae Ia, Q 2, A 1, ad. 2. Herbert Davidson claims that no ontological arguments are to be found in medieval Arabic and Jewish philosophy, which instead concentrate on cosmological arguments that invariably begin from the world, i.e., effects, from which they reason to a first cause or necessarily existent being. See Herbert A. Davidson, Proofs for Eternity, Creation, and the Existence of God in Medieval Islamic and Jewish Philosophy (Oxford: Oxford University Press, 1987), 214-15. However, apart from ontological arguments, Marwan Rashed has argued that al-Fārābī aimed to reconstruct "analytic" proofs that argue from effects as "synthetic" proofs that begin from causes, suggesting that "full-fledged" demonstrations are in fact propter quid. See Marwan Rashed, “Al-Fārābī’s Lost Treatise On Changing Beings and the Pos- 
For it is the greatest proof through which one can know the existence of the deity-I mean the revolution of the heaven $[. .].(1: 70,175)$

On account of [its grandeur], the heaven is called a throne, indicating [...] He who caused them to exist and to move, and who governs this lower world [...] the heaven indicates My existence, grandeur, and power [...] (1:9, 34-35)

[...] the heaven proves to us the existence of the deity, who is its mover and governor, as we shall explain. We shall make it clear that there is no proof indicating to us the existence of the Maker, according to our opinion, like the indication deriving from the heaven. The latter also proves, as we have mentioned, according to the opinion of the philosophers, the existence of the Mover of the heaven and His not being either a body or a force subsisting in a body $(2: 18,302)$.

What is the proof in question? Maimonides says that the heavens prove the existence of God, but he does not tell us what about the heavens constitutes the basis of that proof; there are, in fact, two candidates. Either it is the eternal motion of the spheres from which the philosophers prove the existence of a prime mover or the irregular motions, different velocities, and different directions of the embedded planets which prove the existence of what Maimonides calls a "creator" or "particulariser" who freely chose or willed to originate the spheres. ${ }^{29}$

Now, it is well-known that Maimonides denies that either eternity or creation/ origination can be demonstrated; for this reason, the evidence for eternity and creation must be the empirical observation of the motions of the heavens. That is, each is known from its effects or quia and the most that can be proven is the fact that the world is either eternal or originated (to hoti; inna), not why it is. Thus, lacking a full-fledged explanatory demonstration (propter quid; to dioti; limā), Maimonides does not choose one proof rather than the other (which would rest the existence of God on something less than fully demonstrated), and instead presents his own proof, which is in the form of a Stoic "simple constructive dilemma." 30 In fact, he

sibility of a Demonstration of the Eternity of the World," Arabic Sciences and Philosophy 18, no. 1 (March 2008): 19-58. As we shall argue below, Maimonides' critique of the best argument for the existence of God is not simply that it is from effects and not from a cause-after all God has no causebut, more significantly, that the attempt to causally explain His existence runs into an antinomy. 29 For the former, see the philosophers' twenty-sixth premise (2: Introduction, 239-41); for the latter, 2:19, 310: "To my mind, there is no proof of purpose stronger than the one founded upon the differences between the motions of the spheres and upon the fact that the stars are fixed in the spheres. For this reason you will find that all the prophets used the stars and the spheres as proofs for the deity's existing necessarily."

30 In Stoic terminology, the argument has the form: "If the first, then the third; if the second, then the third; but either the first or the second; therefore in any case the third." William Kneale and Martha Kneale, The Development of Logic (Oxford: Oxford University Press, 1978), 178. It should be noted that this argument form is neither an Aristotelian demonstration nor a syllogism. For an earlier version of the argument, see Ibn Țfayl, Hayy ben Yaqdhân: roman philosophique d'Ibn Thofaïl, ed. and trans. Léon Gauthier (Beirut: Imprimerie catholique, 1936). English translation in Lenn E. Goodman, Ibn Tufayl's Hayy Ibn Yaqzan (Chicago: University of Chicago Press, 2003), 94; Jon McGinnis and David C. Reisman, eds. Classical Arabic Philosophy: An Anthology of Sources (Indianapolis: Hackett Publish- 
presents two versions of this proof- once in 1:71, 181-82, and again in 2:2, 252-the main difference between them consisting in the addition of a last line in the second proof. For reasons of space, I will give only the second version.

1. The fifth body, i.e., the sphere, hence, its motion, must either be subject or not be subject to generation and corruption (i.e., either originated or eternal).

2. [Suppose the sphere is subject to generation and corruption, i.e., originated.] Anything that exists after having been non-existent cannot have brought itself into existence, hence, of necessity must have been brought into existence by something else. (First Intelligible)

3. Therefore, if the sphere is subject to generation and corruption, there must be something else that brought it into existence after having been non-existent.

4. That being is the deity.

5. Therefore, if the sphere is subject to generation and corruption, the deity exists.

6. Suppose now that the sphere is not subject to generation and corruption (i.e., eternal). If it has always and never will cease to be moved in a perpetual and eternal movement, then the mover that causes it to move in this eternal motion is not a body or a force in a body. (Assumes premises 1, 3-11, 14-17, 16 in 2: Introduction)

7. Such a mover is the deity.

8. Therefore, if the sphere is not subject to generation and corruption, the deity exists.

9. But the world has either come into existence after having been non-existent or it has not (i.e., it either is or is not subject to generation and corruption, originated or eternal).

10. Therefore, on both lemmas, the deity exists.

11. This deity who has been proven to exist (according to both lemmas) is the being that necessarily exists by virtue of itself.

In the concluding line (11) - the line not found in the version in 1:71-Maimonides identifies the deity (proven on both lemmas) with the Avicennean Necessary Existent in virtue of itself, i.e., the being that is necessarily existent in itself and is entirely uncaused by anything else, hence, one and simple. ${ }^{31}$ If you were to object that the two lemmas of eternity and creation prove the existence of very different deities, Maimonides's addition of line 11 may be intended to claim that there is only one such ultimate being that is both creator and cause of the first intellect or prime mover. ${ }^{32}$

ing Company, 2007), 290-91. See Joel L. Kraemer, Maimonides: The Life and World of One of Civilization's Greatest Minds (New York: Doubleday Press, 2008), 383.

31 In Stern, Matter and Form, 156-58, I argue that Maimonides uses the term "Creator" to designate the Avicennean Necessary Existent in Itself, based on his description in Guide 1:69, 169-70 which he in turn identifies with the Particulariser in 2:19, 303; 310; 2:20, 314; and 2:15, 449-51.

32 For example, see Harvey, "Maimonides' First Commandment," 153; Harvey, Physics and Metaphysics in Hasdai Crescas (Amsterdam: Gieben, 1998), 77-82; Harvey, "Maimonides' Critical Epistomology," 228-30; Kraemer, "How (not) to Read," 17; Kraemer, "Is There a Text," 365, who both see the two lemmas leading to different conceptions of the deity, one of the kalām or Bible, and one of the philosophers. Harvey, Physics, provides a very good review and analysis of the classical commentators (including ibn Tibbon, Joseph Kaspi, Profayt Duran [Efodi], and Hasdai Crescas), who all take Maimonides's reference to the Necessary Existent in Itself to be based on the third of the philosophers' proofs in Guide 2:1, thereby creating a contradiction internal to the Guide. On my view, Maimonides's 
Maimonides repeatedly refers to this proof as a "method of demonstration about which there can be no doubt" $(1: 71,180)$, by which "perfect certainty is obtained" $(1: 71,181)$, and "as to which there is no disagreement in any respect" $(1: 71,182)$. Given this praise, I take it that the constructive dilemma is the "greatest proof" to which Maimonides is referring in the passages quoted earlier from 1:70, 1:9, and $2: 18$. The proof is so certain and indubitable that one would assume that it also yields 'ilm, or scientific knowledge, that God exists.

Yet, at the end of his long discussion of the set of incompatibilities between Ptolemaic astronomy and Aristotelian cosmology that led to the "crisis of the sciences" in twelfth-century Andalusia, Maimonides writes:

For it is impossible for us to accede to the points starting from which conclusions may be drawn about the heavens; for the latter are too far away from us and too high in place and in rank. And even the general conclusion that may be drawn from them [the heavens], namely, that they prove the existence of their Mover, is a matter the knowledge of which cannot be reached by human intellects (2:24, 327, my emphasis).

This passage has been the subject of much recent controversy, ${ }^{33}$ but what Maimonides literally says is that there is a proof-prima facie, the constructive dilemmafrom the heavens to the existence of "their Mover" but that its conclusion is not something of which the human intellect has knowledge. How is that possible? If the constructive dilemma is a proof and, indeed, certain, why isn't it knowledge? And if it is not knowledge, how could it be a proof whose conclusion is believed with certainty?

My answer in brief is that the proof may move us to assent to its conclusionafter all, its two lemmas exhaust the possibilities and, therefore, it is necessary and certain-but it is not knowledge because our assent to the premises of the two lemmas, eternity and origination, is only based on their observable effects, the spheres' unending motion and irregular, different motions, respectively, and from the premises of eternity and origination, we in turn infer the deity, the necessarily existent being, as their cause. Hence, the proof is doubly quia: the existence of God is proven from His effects twice over, and we lack any explanatory cause of the conclusion that would yield understanding, knowledge, or 'ilm/epistēmē. Thus "the greatest proof" is simply the best we humans can do, the proof no greater than which is known by any human: indubitable, certain, and even necessarybut, lacking any explanation, "a matter the knowledge of which cannot be reached by human intellects."

However, this is not the end of Maimonides's story. One might take Maimonides's argument to show, as did his fourteenth-century commentator Moses of Narbonne,

own proof is not that of the philosophers but the proof in Guide 2:2, thus avoiding any contradiction, although the proof nonetheless furnishes no knowledge.

33 See the symposium of papers in Aleph 8 (2008). 
that "[The existence of God cannot be demonstrated] from prior [causes] because He [...] is prior to all and nothing is prior to Him. How could [His existence] be explained by a demonstration from the cause when He is the cause of everything and everything is His creation?" 34 But this only prompts the objection: If God's existence necessarily has no cause, why should the fact that we cannot give a cause or explanation count against our knowledge of His existence? There exists no cause we do not know. Why, then, shouldn't a certain, necessary, and indubitable quia demonstration suffice for (scientific) knowledge of this conclusion? Without some idea of what we do not understand, there is no punch to the sceptic's challenge.

Contrary to Narbonne, I want to propose that Maimonides's claim that we have no knowledge of the existence of the deity on the basis of this proof is not because God has no prior cause, true though that is. The real problem is that the attempt to provide an explanation of God's existence runs into an antinomy. The best explanation of the existence of God rests on contradictory premises: each is individually well-motivated but together they are incompatible. For Maimonides, this tension signals our incomplete understanding of the notions in question.

Maimonides presents this antinomy through an extended parable scattered throughout the Guide about a ruler who is known by his subjects only by means of his actions of governance. ${ }^{35}$ However, for reasons of space, I will sketch the objection Maimonides raises by focusing on the two conflicting principles on which it rests. One is about final ends, the other about the structure of immaterial causation, a relation for which Maimonides appropriates the Neoplatonic term for emanation or overflowing, in Arabic fayḍ.

The principle about final ends is that "The end is nobler than the things that subsist [or act] for the sake of the end" $(2: 11,275)$. The principle about emanation is that the direction of emanation is always from the more noble to the less noble. ${ }^{36}$ Now, if we were to explain God's emanation of the world, it presumably would be by way of its final cause, the good it achieves. That good will never be a benefit for God (for how can He be benefited by His own act?) but necessarily a benefit for the world. However, according to the first principle, final ends must be more noble than what subsists or acts for their sake and, according to the second, emanation goes from the more noble to the less. So, either the final cause of the emanation would necessarily be something more noble than the deity or divine emanation, or emanation would proceed from the less to the more noble-both of which are absurd. Therefore, Maimonides concludes: "[Whenever an immaterial being, e.g., a separate intellect or the deity] causes a certain good thing to overflow from it, [...] the exis-

34 Moses Narbonne, Der Commentar des Rabbi Moses Narbonensis su dem werke More Nebuchim des Maimonides, ed. and trans. Jakob Goldenthal (Wien: K.K. Hof- und Staatsdruckerei, 1852), 15b-16a. 35 For the parable of the ruler, see Guide 1:46, 97-98; 1:69, 168-71; 1:70, 175; 3:13, 454; and Stern, Matter and Form, 168-77.

36 On Maimonides's understanding of emanation, overflowing, or fayḍ, see Guide 2:12, 278-80; 3:22, 317-20. 
tence, the purpose, and the end of the being conferring the benefits do not consist in conferring the benefits on the recipients" $(2: 11,275) .{ }^{37}$ The emanation of goods is never for the sake of anything else; instead there is simply a "residue" that suffices, or overflows, to perfect something else as a necessitated by-product of the divine cause. In quasi-ethical terms, emanation is an expression of grace, which is indeed one way to translate the Arabic term fayd. But this conclusion has a cost: without a final cause for the sake of which the emanating being subsists or the emanation acts, we cannot explain the causal relation between God (or a separate intellect) and the sublunary world, and, without an explanation, we have no understanding of emanation, hence, no knowledge. ${ }^{38}$

Before I turn to Maimonides's diagnosis of the source of this failure of apprehension, I want to sketch a second Maimonidean argument that shows the impossibility of knowledge of a class of metaphysical propositions. This argument is laid out in Maimonides's discussion of divine attributes which culminates in his frequently discussed via negativa or, more precisely, his analysis of categorial negations of privative attributive statements about God. Contrary to the dogmatic reading according to which Maimonides uses these negations to furnish us with knowledge about Godknowledge of what He is not-I shall argue for the sceptical reading that Maimonides argues that even these statements furnish no knowledge, not even knowledge of what He is not! ${ }^{39}$

There are three background concepts that must be unpacked. First, because the dogmatist against whom Maimonides's argument seems to be directed is Avicenna, the distinguishing fact about God is His unity, not merely that He is numerically one, but that He is also indivisible, absolutely simple, incomposite, and, insofar as He has no parts or structure that would require any explanation of His unity, absolutely uncaused. This is what is meant by saying that God is necessarily existent in itself, from which it also follows that He is incomparable and unique. Maimonides also transforms the Avicennean God's metaphysical uniqueness into a semantic thesis that all predicates that apply to God and to creatures are totally equivocal and, because all our understanding of linguistic terms derives from their application to creatures, it follows that we have no understanding of any of the predicates that apply to God. (Here we see Maimonides shifting from an ad hominem argument, directed against

37 In more general terms: Whenever a being $b$ of rank $n$ emanates a good or benefit on a being $c$ of rank $n-1-$ which is necessarily the case because the direction of emanation is from the higher rank to the lower rank-the final cause or end of (the subsistence or act of) $b$ cannot consist in emanating that good onto $c$.

38 For a similar objection, see al-Fārābī, Risāla fĩ al- 'Aql, ed. M. Bouyges (Beirut: 1938), 30. English Translation by Arthur Hyman: "Letter on the Intellect." In Philosophy in the Middle Ages, ed. Arthur Hyman and James J. Walsh (Indianapolis: Hackett, 1983), 219. Al-Fārābī criticises those who explain why forms descend to this world by the final cause "so that matters attain a more perfect existence" because that "contradicts what Aristotle has shown" that the end must always be more noble than that which it acts for the sake of.

39 For a more detailed exposition of this argument, see Stern, Matter and Form, 191-249. 
his Avicennean dogmatist, to his own sceptical stance.) Conversely, on this Avicennean conception, belief in a deity that is not uncaused or is a plurality, divisible, or composite is belief in something other than God; it is idolatry or polytheism, the false belief that God is not one, hence, material and even bodily. What Maimonides will argue against the dogmatist is that, in his attempt to provide a theory of our knowledge of divine unity, he ends up with idolatry.

Second, Maimonides argues that the objects of belief and knowledge are not words-the sounds that come out of our mouths that he calls "external speech"but mental representations (tașawwur), the system of which he calls "inner speech," the language of thought, which he thinks of as a language in its own right, as it were, with its own linguistic structure and syntax. This is to say two things. First, there is no cognition without representation. So, if no consistent, coherent inner representation corresponds to a string of words in external speech, one just mouths sounds instead of expressing beliefs (1:50,111-12). Second, the expressive resources of inner speech, or of the mental representations, must be adequate to the demands of knowledge, and in at least the natural or sublunary sciences they are. Unlike the grammars of external speech that are conventional and vary across linguistic communities, the syntax of the language of inner representation is universal and, insofar as it is structured in ways that perspicuously reveal logical relations, it is therefore the preferred system of representations to guide one to knowledge in the sciences. ${ }^{40}$ Nevertheless, however superior the inner mental representations are to external speech, they are also composed according to a syntax. As a consequence, they also will be problematic when it comes to expressing truths about metaphysics and, in particular, about the absolutely simple God.

Third, Maimonides assumes a significant constraint on all representations, including those of inner speech, if they are to count as knowledge. Not only must the representation be true; its content must correspond to what exists in the world. To this Maimonides adds the condition that, in order to serve as an object of knowledge, a true representation must not only represent what is the case: how it represents what it represents must also be the case.

So, a statement about God, such as (1) "God is one" is true not only if and only if God is one, the statement must also represent Him as one. In particular, it cannot represent Him as if He were a composite being with a substratum or essence and at-

40 See Maimonides’ Treatise on Logic (Maḳālah fi-Șinā'at al-Manțik), trans. and ed. Israel Efros, Proceedings of the American Academy of Jewish Research 8 (1937-38), chapter 14. Arabic in Efros, "Maimonides' Arabic Treatise on Logic," Proceedings of the American Academy of Jewish Research 34 (1966). On al-Fārābī's influence on Maimonides's conception of logic here, see Josef Stern, "Maimonides on Language and the Science of Language," in Maimonides and the Sciences, ed. Robert S. Cohen and Hillel Levine (Dordrecht: Kluwer, 2000), 173-226; and for the Farabian background, the Introduction to Fritz W. Zimmermann, Al-Farabi’s Commentary and Short Treatise on Aristotle's De Interpretatione (Oxford: Oxford University Press, 1981). 
tributes or accidents. With this constraint in place, Maimonides argues that there can be no representation by which we can know, for example, that God is one is true.

Suppose Maimonides's dogmatist opponent, the philosopher, demonstrates (1): that God is one, an absolute unity, simple, and incomposite. ${ }^{41}$ Keep in mind that no term including "one” applied to God has the same content it possesses when applied to any other creature and, furthermore, we also simply do not understand its content. But even apart from its pure equivocality, the predicate "is one," insofar as it is a predicate or attribute-term, designates some affirmative attribute, or "possession," which is either essential or accidental, i.e., part of God's essence or a contingent attribute separate from His essence. In either case the dogmatist next needs to explain why the complex essence, or essence-attribute combo, constitute one being; he needs a cause. But God, he has said, is necessary in itself and uncaused. Hence, in demonstrating that God is one, the dogmatist has represented Him in a way that in turn requires an explanatory cause, contradicting his assertion that God is absolutely uncaused. In short, he has misrepresented Him and indeed ended up with idolatry.

Accordingly, you have not arrived at a knowledge of the true reality of an essential attribute, but you have arrived at multiplicity. For you believe that He is a certain essence possessing unknown attributes [...] for if you say God [...] is a certain substratum upon which certain borne things are superposed and that this substratum is not like these adjuncts, the utmost of our apprehension would be, on the basis of this belief, polytheism and nothing else. For the notion of the substratum is different from that of the adjunct borne by it $(1: 60,144-45)$.

To avoid this contradictory metaphysical consequence of affirmative attribution, Maimonides proposes to the dogmatist that he might translate or regiment the external speech statement, the affirmative (1), in inner speech as (2), the categorical negation of the privation ("is many") corresponding to the affirmative attribute or possession ("is one"): (2) "Not (God is many)." A categorial negation denies that the subject (here: God) falls under whatever category to which the predicate in question ("is many") belongs. So, to use Maimonides's own example $(1: 59,136)$, (3) "A wall does not see" does not say that a wall is blind but that it does not fall in the category of thing that is either seeing or blind. And a privation, in turn, is the absence of the possession of an attribute in a subject in which the attribute ought to exist or normally does exist. So, blindness is a privation in creatures who, by nature, ought to have sight. Now, privations, being absences, are not parts of anything, hence, they avoid the problem of part-hood, hence, divisibility, created by affirmative attributes. But Maimonides also emphasises that they are nonetheless attributes attributed, or predicated, to subjects and that, like affirmative attributes, they serve to individuate

41 Note that Maimonides is arguing with the dogmatist, the faylasūf, on his grounds, on his assumption that the deity is the necessary existent. 
subjects. ${ }^{42}$ So, privations avoid the problem of divisibility, and the categorial negation in turn denies that the subject belongs to the superordinate category to which the privation (and its positive possession) belongs, hence, they doubly negate any complexity of God. Nonetheless, while these categorial negations are better than affirmative attributions to God, Maimonides argues they are still not good enough. In particular, they fail the condition that how what is represented is represented must also be true. "For there is no oneness at all except in believing that there is one simple essence in which there is no complexity [tarkīb; lit. "composition"] [...] and you will not find therein any multiplicity either in the thing as it is outside of the mind or as it is in the mind [...]" (1:51, 113, my emphasis).

Even though (2) is better than (1), its subject-predicate syntax still implies that there exists an attribute (signified by the predicate) formally distinguishable from the substratum or substance (signified by the subject term), and this structural division holds even if the attribute is privative and categorically negated. So, negated privative attributes are still subject to all problems of attribution from which Maimonides concludes: “[...] negation does not give knowledge in any respect of the true reality of the thing with regard to which the particular matter in question has been negated" $(1: 59,139)$. So, whenever we can demonstrate that God is one or, in regimented inner speech, the (categorial) negation of (the privation of) multiplicity/compositeness, it is nonetheless presupposed (hence, entailed) from the syntactic form of the demonstrated proposition that He is composite! This problem for divine attribution-which I call the "syntactic problem" of divine attributes-infects all attribution, affirmative and negative. Maimonides, contrary to common opinion, is not an advocate but a sceptical critic of negative theology. And again, the philosophers' theory that attempts to capture divine unity ends up also representing God in an idolatrous form.

Without pursuing this antimony further, it puts Maimonides in the state of spontaneous awe and praise of God in the passages we quoted earlier (1:58, 137 and 1:59, 139). However, given his own critique of the possibility of expressing truths about God in language, what form can that praise take?

\footnotetext{
The most apt phrase concerning this subject is the dictum occurring in the Psalms, Silence is praise to Thee (Psalms 65:2), which interpreted signifies: silence with regard to You is praise [...] Accordingly, silence and limiting oneself to the apprehensions of the intellects are more appropriate-just as the perfect ones have enjoined when they said: Commune with you own heart upon your bed, and be still. Selah (Psalms 4:5) (1:59, 139-40).
}

The silence in this passage is not only silence in external but also in inner speech: neither affirmative nor negative privative attributions express truths, hence, praise 
of God. ${ }^{43}$ The silence is also an expression of epoche. By holding back from representing God using a false expression, thereby acknowledging the limitations of one's representational powers, one expresses God's greatness. At the same time, the silence is conjoined with "limiting oneself" to the domain in which there are "apprehensions of the intellect" in which knowledge is possible. Silence with respect to metaphysics goes along with continuing skepsis in the sublunar domain of natural science.

To return finally to Maimonides's diagnosis of his scepticism with respect to knowledge of metaphysics, his ultimate explanation of the human epistemic condition is that he is a hylomorphic substance whose matter limits the extent which his form or intellect can be actualised. ${ }^{44}$ As he writes in explanation of why he cannot have knowledge of the existence of the deity: "[God] has enabled man to have knowledge of what is beneath the heavens, for that is his world and his dwelling place" (2:24, 327)-i.e., as a composite material substance, the human's natural place is the world of the elements, and it is there that he can achieve knowledge. But among his material, or bodily, faculties, a particular source of the sceptical limitations on the human intellect is his imagination. ${ }^{45}$ As we saw with the syntactic problem of divine attributes, our human intellects must apprehend God through inner speech representations that necessarily employ composite subject-predicate syntax. Why "necessarily"? Because, as embodied intellects, we can never free our representation of an existent from the influence of the body, forced by our "wish to preserve the conception of the imagination" $(1: 51,114)$.

For Maimonides, this representational role of the imagination is a general obstacle to knowledge of immaterial beings. Not only is the one God conceived in corporeal terms as an essence or substratum with attributes (1:51, 114). Similar antinomies

43 Maimonides employs Psalms 4:5 three times in the Guide. In 1:50, 112, the silence is of external speech; in 1:59, 140 it is of inner speech; and in 2:5, 260, he uses the verse to illustrate that the true praise of God, like that of the spheres (literally), is articulated in mental representations, not through "speech of lip and tongue.” The image of Psalms 4:5 also underlies Maimonides's claim in 3:51, 623 that "true intellectual worship" of God occurs in those rare moments "when you are alone with yourself, and no one else is there and while you lie awake upon your bed."

44 Because this possibility is a fact about humans, hence, about something in the sublunar sphere, and not metaphysics, Maimonides can allow himself this diagnosis.

45 Unlike other Arabic philosophers who posit distinct faculties of imagination for each of these functions, Maimonides posits one faculty with multiple functions: retention of material forms corresponding to sense impressions, the composition of given forms into more complex ones and division of others, and the representation of truths (as propositions with, for example, essences as subjects and attributes in predicate position). Note that the last role of the imagination is problematic only when it is called upon to represent immaterial beings that are absolutely simple; the representation of composite material substances using composite structures is perfectly fine. In addition, Maimonides identifies the imagination with the "evil impulse" and the source of all deficiencies of reason and character (2:12, 280). Indeed, I know of no medieval philosopher other than Maimonides who assigns such a negative valence to the imagination and sees as much tension between it and the intellect. Among Maimonides's many references to the imagination in the Guide, see Maimonides 1:46, 98; 1:51, 114; and 1:73, 208-11. 
arise, as we saw, with the idea of emanation (fayd) which Maimonides regards as the best available figure to express the causality of an immaterial being even though it is inadequate to the task of expressing the "true reality": "For the mental representation of the action of one who is separate from matter is very difficult, in a way similar to the difficulty of the mental representation of the existence of one who is separate from matter" (2:12, 279). Again, the difficulty is that the imagination, a bodily faculty, cannot represent any existent except as a body or any action except as a spatio-temporal event. Recall that it is through a parable (of the ruler's beneficence to his subjects)-i.e., an imaginative product-that Maimonides articulates the emanational final causal relation and exposes what we do not understand as glimpsed in the antinomy to which it leads.

Maimonides's objection, however, is not simply Aristotle's point that no intellection or intellectual representation is possible without imagination, but rather that we have no principled way to distinguish between the two. ${ }^{46}$ For example, in order for demonstration to serve as the basis of scientific knowledge, we must be able to distinguish between the necessary, the possible, and the impossible. But are these modalities to be determined by the intellect and by science (i.e., that the possible is a potentiality that will be actualised at some point in infinite time) or by what is admissible to the imagination (i.e., by mental judgments about equal alternatives among which we choose to act)? What we need, Maimonides tells us, is a criterion "that would enable us to distinguish the things cognized intellectually from those imagined" $(1: 73,211)$. Nonetheless, when pushed to produce this criterion, Maimonides concedes that he possesses no such principle "that permits differentiation between the imaginative faculty and the intellect" $(3: 15,460)$. If there were one, would it be "something altogether outside both the intellect and the imagination, or is it by the intellect itself that one distinguishes between that which is cognized by the intellect and that which is imagined?" $(3: 15,461) .{ }^{47}$

Of course, this question is no surprise. If our matter prevents our intellects from apprehending the immaterial, it will prevent us from clearly distinguishing the actualised intellect from bodily faculties like the imagination. And without a criterion to distinguish them, there can be no principled scientific knowledge. Maimonides concludes: "these are points for investigation which may lead very far" (3:15, 460): they are the stuff of skepsis, enquiry that never terminates in knowledge.

46 Aristotle, On the Soul 2.7.431a16.

47 See Emil Fackenheim, "The Possibility of the Universe in Al-Farabi, Ibn Sina and Maimonides," Proceedings of the American Academy for Jewish Research 16 (1946/47): 60n61. 


\section{Bibliography}

Altmann, Alexander. "Maimonides on the Intellect and the Scope of Metaphysics." In Von der mittelalterlichen zur modernen Aufklarung, 60-129. Tübingen: J.C.B. Mohr, 1987.

Barnes, Jonathan. "The Beliefs of a Pyrrhonist." Elenchos 4 (1983): 5-43.

Black, Deborah L. "Knowledge (' $/ \mathrm{lm})$ and Certitude (Yaqīn) in Al-Farabi's Epistemology." Arabic Sciences and Philosophy 16, no. 1 (March 2006): 11-45.

Bosley, Richard and Tweedale, Martin, eds. Basic Issues in Medieval Philosophy. Second edition. Toronto: Broadview, 2006.

Burnyeat, Myles. "Aristotle on Understanding Knowledge." In Aristotle on Science, edited by Enrico Berti, 97-139. Padua: Antenore, 1981.

Burnyeat, Myles. "Can the Skeptic Live His Skepticism?” In The Skeptical Tradition, edited by Myles Burnyeat, 117-48. Berkeley: University of California Press, 1983.

Burrell, David B. Knowing the Unknowable God: Ibn-Sina, Maimonides, Aquinas. Notre Dame: University of Notre Dame Press, 1986.

Cook, Michael. Early Muslim Dogma. Cambridge: Cambridge University Press, 1981.

Crone, Patricia. "Ungodly Cosmologies." In Islam, the Ancient Near East and Varieties of Godlessness: Collected Studies in Three Volumes, Volume 3, edited by Hanna Siurua, 118-50. Leiden: Brill, 2016.

Davidson, Herbert A. "Maimonides on Metaphysical Knowledge." Maimonidean Studies 3 (1995): 49-103.

Davidson, Herbert A. Maimonides the Rationalist. Oxford: Littman Library of Jewish Civilization, 2011.

Davidson, Herbert A. "The Problematic Passage in Guide for the Perplexed 2:24." Aleph 8 (2008): 163-93.

Davidson, Herbert A. Proofs for Eternity, Creation, and the Existence of God in Medieval Islamic and Jewish Philosophy. Oxford: Oxford University Press, 1987.

Dobbs-Weinstein, Idit. Maimonides and St. Thomas on the Limits of Reason. Albany: State University of New York Press, 1995.

Fackenheim, Emil. "The Possibility of the Universe in Al-Farabi, Ibn Sina and Maimonides." In Proceedings of the American Academy for Jewish Research 16 (1946/47): 39-70.

Al-Fārābī, Abu Nașr. Kitāb al-Burhān. In Al-Manțiq 'inda al-Fārābī, volume 4, edited by Majid Fakhry. Beirut: Dar al-Machreq, 1987. Partial English translation in Arabic Philosophy: An Anthology of Sources, edited and Translated by Jon McGinnis and David C. Reisman, 63-67. Indianapolis: Hackett Publishing Company, 2007.

Al-Fārābī, Abu Nașr. Risāla fĩ al-'Aql, edited by M. Bouyges. Beirut: 1938. English Translation by Arthur Hyman: "Letter on the Intellect." In Philosophy in the Middle Ages, edited by Arthur Hyman and James J. Walsh, 215-21. Indianapolis: Hackett, 1983.

Fraenkel, Carlos. "Maimonides, Averroes, and Samuel Ibn Tibbon on a Skandalon of Medieval Science." Aleph 8 (2008): 195-212.

Frede, Michael. "The Skeptic’s Beliefs.” In Essays in Ancient Philosophy, 179-200. Minneapolis: University of Minnesota Press, 1987.

Frede, Michael. "The Skeptic's Two Kinds of Assent and the Question of the Possibility of Knowledge." In Essays in Ancient Philosophy, 201-22. Minneapolis: University of Minnesota Press, 1987.

Hadot, Pierre. Philosophy as a Way of Life. Edited by Arnold I. Davidson, translated by Michael Chase. Oxford: Blackwell, 1995.

Hadot, Pierre. What is Ancient Philosophy? Translated by Michael Chase. Cambridge: Harvard University Press, 2002. 
Harvey, Warren Zev. “Maimonides' Critical Epistemology and Guide 2:24.” Aleph 8 (2008): 213-35. Harvey, Warren Zev. "Maimonides' First Commandment, Physics, and Doubt." In Hazon Nahum:

Studies in Jewish Law, Thought, and History, presented to Dr. Norman Lamm on the occasion of his seventieth birthday, edited by Jacob Elman and Jeffrey S. Gurock, 149-62. New York: Yeshiva University Press, 1997.

Harvey, Warren Zev. Physics and Metaphysics in Hasdai Crescas. Amsterdam: Gieben, 1998.

Harvey, Warren Zev. "A Third Approach to Maimonides' Cosmogony-Prophetology Puzzle." Harvard Theological Review 74, no. 3 (July 1981): 287-301.

Heschel, Abraham Joshua. “The Quest for Certainty in Saadia's Philosophy.” Jewish Quarterly Review 33, no. 3 (January 1943): 265-313.

Horowitz, Saul. Der Einfluss der griechischen Skepsis auf die Entwicklung der Philosophie bei den Arabern. Breslau: Schatzky, 1915.

Hyman, Arthur. "Demonstrative, Dialectical, and Sophistic Arguments in the Philosophy of Maimonides." In Moses Maimonides and His Time, edited by Eric Ormsby, 35-51. Washington D.C.: Catholic University of America Press, 1989.

Ibn Falaquera, Shem Tov. Moreh ha-Moreh. [in Hebrew.] Edited by Yair Shiffman. Jerusalem: World Union of Jewish Studies, 2001.

Ibn Ṭufayl. Hayy ben Yaqdhân: roman philosophique d'lbn Thofä̈l. Edited and translated by Léon Gauthier. Beirut: Imprimerie catholique, 1936. English translation: Lenn E. Goodman. Ibn Tufayl's Hayy Ibn Yaqzan. Chicago: University of Chicago Press, 2003. Partial English translation in Arabic Philosophy: An Anthology of Sources, edited and Translated by Jon McGinnis and David C. Reisman, 284-93. Indianapolis: Hackett Publishing Company, 2007. Ivry, Alfred. "Guide 2:24 and All That (i)jâza." Aleph 8 (2008): 237-46.

Ivry, Alfred. "The Logical and Scientific Premises of Maimonides' Thought." In Perspectives on Jewish Thought and Mysticism, edited by Alfred. L. Ivry, Elliot R. Wolfson, and Allan Arkush, 63-97. Amsterdam: Harwood, 1998.

Kneale, William and Martha Kneale. The Development of Logic. Oxford: Oxford University Press, 1978.

Kogan, Barry S. "What Can We Know and When Can We Know It? Maimonides on the Active Intelligence and Human Cognition." In Moses Maimonides and His Time, edited by Eric Ormsby, 121-37. Washington D.C.: Catholic University of America Press, 1989.

Kraemer, Joel L. "How (Not) to Read The Guide of the Perplexed." Jerusalem Studies in Arabic and Islam 32 (2006): 350-403.

Kraemer, Joel L. “Is There a Text in this Class?" Aleph 8 (2008): 247-99.

Kraemer, Joel L. Maimonides: The Life and World of One of Civilization's Greatest Minds. New York: Doubleday Press, 2008.

Kraemer, Joel L. "Maimonides on Aristotle and Scientific Method." In Moses Maimonides and His Time, edited by Eric Ormsby, 53-88. Washington D.C.: Catholic University of America Press, 1989.

Kreisel, Howard. Maimonides' Political Thought: Studies in Ethics, Law, and the Human Ideal. Albany: SUNY Press, 1999.

Kukkonen, Taneli. "Al-Ghazali’s Skepticism, Revisited." In Rethinking the History of Skepticism: The Missing Medieval Background, edited by Henrik Lagerlund, 29-60. Leiden: Brill, 2010.

Lagerlund, Henrik. "A History of Skepticism in the Middle Ages." In Rethinking the History of Skepticism: The Missing Medieval Background, edited by Henrik Lagerlund, 1-28. Leiden, Boston: Brill, 2010.

Langermann, Y. Tzvi. “My Truest Perplexities.” Aleph 8 (2008): 301-17.

Maimonides, Moses. The Guide of the Perplexed. Translated by Shlomo Pines. 2 volumes. Chicago: University of Chicago Press, 1963. 
Maimonides, Moses. Maimonides' Treatise on Logic (Makālah fi-Șinā'at al-Manțik). Edited and translated by Israel Efros. Proceedings of the American Academy of Jewish Research 8 (193738): 1-65 (English section); 66-136 (Hebrew section). Arabic in Efros, "Maimonides' Arabic Treatise on Logic," Proceedings of the American Academy of Jewish Research 34 (1966), English introduction 155-60, Arabic text 1-42.

Maimonides, Moses. Moreh Nevukhim. [in Hebrew.] Translated by Michael Schwartz. 2 vols, Tel Aviv: Tel Aviv University Press, 2002.

Manekin, Charles H. "Belief, Certainty, and Divine Attributes in the Guide of the Perplexed." Maimonidean Studies 1 (1990): 117-41.

Manekin, Charles H. "Maimonides and the Arabic Aristotelian Tradition of Epistemology." In Beyond Religious Borders: Interaction and Intellectual Exchange in the Medieval Islamic World, edited by David M. Freidenreich and Miriam Goldstein, 78-95. Philadelphia, PA: University of Pennsylvania Press, 2011.

McGinnis, Jon, and David C. Reisman, eds. Classical Arabic Philosophy: An Anthology of Sources. Indianapolis: Hackett Publishing Company, 2007.

Narbonne, Moses. Der Commentar des Rabbi Moses Narbonensis su dem werke More Nebuchim des Maimonides. Edited and translated by Jakob Goldenthal. Vienna: K.K. Hof- und Staatsdruckerei, 1852.

Pasnau, Robert. "Science and Certainty." In Cambridge History of Medieval Philosophy, vol. 1, edited by Robert Pasnau, 357-68. Cambridge: Cambridge University Press, 2010.

Pasnau, Robert. Thomas Aquinas on Human Nature: A Philosophical Study of Summa Theologiae, 1a 75-89. Cambridge: Cambridge University Press, 2002.

Perin, Casey. "Scepticism and Belief." In Cambridge Companion to Ancient Scepticism, edited by Richard Bett, 145-64. Cambridge: Cambridge University Press, 2010.

Perler, Dominik. "Does God Deceive Us? Skeptical Hypotheses in Late Medieval Philosophy." In Rethinking the History of Skepticism: The Missing Medieval Background, edited by Henrik Lagerlund, 171-92. Leiden, Boston: Brill, 2010.

Perler, Dominik. "Skepticism." In Cambridge History of Medieval Philosophy, vol. 1, edited by Robert Pasnau, 384-96. Cambridge: Cambridge University Press, 2010.

Perler, Dominik. "Scepticism and Metaphysics." In The Oxford Handbook of Medieval Philosophy, edited by John Marenbon, 546-65. Oxford: Oxford University Press, 2012.

Perlmann, Moshe. "Ibn Hazm on the Equivalence of Proofs." Jewish Quarterly Review 40, no. 3 (January 1950): 279-90.

Pines, Shlomo. “Dieu et L'Etre Selon Mamonide: Exégese d'Exode 3,14 et doctrine connexe." In Celui Qui Est: Interprétations Juives et Chrétiennes d'Exode 3-14, edited by Alain de Libera and Émilie Zum Brunn, 15-24. Paris: Cerf, 1986.

Pines, Shlomo. "The Limitations of Human Knowledge According to Al-Farabi, Ibn Bajja, and Maimonides." In Studies in Medieval Jewish History and Literature, Vol. 1, edited by Isadore Twersky, 82-109. Cambridge: Harvard University Press, 1979.

Pines, Shlomo. "Les limites de la métaphysique selon al-Farabi, Ibn Bajja, et Maimonide: sources et antitheses de ces doctrine chez Alexandre d'Aphrodise et chez Themistius." Miscellanea Mediaevalia 13, no.1 (1981): 211-25.

Pines, Shlomo. "The Philosophical Purport of Maimonides' Halakhic Works and the Purport of the Guide of the Perplexed." In Maimonides and Philosophy, edited by Shlomo Pines and Yirmiyahu Yovel, 1-14. Dordrecht: Nijhoff, 1987.

Pines, Shlomo. "Translator's Introduction." In Maimonides, Guide of the Perplexed, translated by Shlomo Pines, 1:Ivii-cxxxiv. 2 volumes. Chicago: University of Chicago Press, 1963.

Rashed, Marwan. "Al-Fārābī's Lost Treatise On Changing Beings and the Possibility of a Demonstration of the Eternity of the World." Arabic Sciences and Philosophy 18, no. 1 (March 2008): 19-58. 
Rosenthal, Franz. Knowledge Triumphant. Leiden: Brill, 1970.

Rubio, Mercedes. Aquinas and Maimonides on the Possibility of the Knowledge of God. An Examination of the Quaestio de attributis. Dordrecht: Springer, 2008.

Rudavsky, Tamar. Maimonides. Malden, MA: Wiley-Blackwell, 2010.

Gaon, Saadia. Sefer Emunot we-De'ot. [in Hebrew.] Translated by Joseph Qafih. Jerusalem: Surah Press, 1969/70. English translation: Samuel Rosenblatt. Saadia Gaon: The Book of Beliefs and Opinions. New Haven: Yale University Press, 1948.

Seeskin, Kenneth. Searching for a Distant God. Oxford: Oxford University Press, 1999.

Stern, Josef. The Epistemology of Prophecy: Maimonides on the False Prophet. Manuscript in preparation.

Stern, Josef. “Maimonides' Demonstrations: Principles and Practice." Medieval Philosophy and Theology 10 (2001): 47-84.

Stern, Josef. "Maimonides on Language and the Science of Language." In Maimonides and the Sciences, edited by Robert S. Cohen and Hillel Levine, 173-226. Dordrecht: Kluwer, 2000.

Stern, Josef. The Matter and Form of Maimonides' Guide. Cambridge: Harvard University Press, 2013.

Strauss, Leo. "The Literary Character of the Guide of the Perplexed." In Persecution and the Art of Writing, 38-94. Glencoe: Free Press, 1952.

Striker, Gisela. "Academics versus Pyrrhonists, Reconsidered." In Cambridge Companion to Ancient Scepticism, edited by Richard Bett, 195-207. Cambridge: Cambridge University Press, 2010.

Striker, Gisela. "On the Difference between the Pyrrhonists and the Academics." In Essays on Hellenistic Epistemology and Ethics, 135-49. Cambridge: Cambridge University Press, 1996.

Striker, Gisela. "Sceptical Strategies." In Doubt and Dogmatism, edited by Malcolm Schofield, Myles Burnyeat, and Jonathan Barnes, 54-83. Oxford: Oxford University Press, 1980.

Striker, Gisela. "Scepticism as a Kind of Philosophy." Archiv für Geschichte der Philosophie 83, no. 2 (August 2001): 113-29.

Taylor, Richard C. "Maimonides and Aquinas on Divine Attributes: The Importance of Avicenna." In Maimonides' Guide of the Perplexed in Translation: A History from the Thirteenth Century to the Twentieth, edited by Josef Stern, James T. Robinson, and Yonatan A. Shemesh. Chicago: University of Chicago Press, forthcoming 2019.

Van Ess, Josef. "Skepticism in Islamic Religious Thought." Al-Abhāt 21 (1968): 1-15.

Wolfson, Harry A. Repercussions of the Kalam in Jewish Philosophy. Cambridge, MA: Harvard University Press, 1979.

Zimmermann, Fritz W. Al-Farabi's Commentary and Short Treatise on Aristotle's De Interpretatione. Oxford: Oxford University Press, 1981. 
